\title{
Ofício das Trevas: Alceu Amoroso Lima NA NOITE DO ARBÍTRIO'
}

\author{
TENEBRAE SERVICE: AlCEU AMOROSO LIMA IN THE SHADOWS OF THE DICTATORSHIP
}

MARCELO Timotheo da Costa $\left(^{*}\right)$

Para Lucia Ribeiro e Luiz Alberto Gomez de Souza

\begin{abstract}
RESUMO
O presente artigo analisa como o intelectual e líder leigo católico Alceu Amoroso Lima (18931983) reagiu à decretação do Ato Institucional número 5, que aprofundou o caráter autoritário de nossa última ditadura (1964-1985). Para tanto, serão examinadas as cartas diárias que Amoroso Lima endereçou à filha, a monja beneditina Maria Teresa, ao longo do ano de 1969. Tratava-se, para o mencionado intelectual, de reorganizar sua atuação pública à luz de sua fé e frente aos desafios e urgentes demandas daquele tempo de profunda crise. Ação esta para a qual o referido diálogo epistolar com Maria Teresa foi de fundamental importância.
\end{abstract}

Palavras-chave: Pensamento Católico Brasileiro. Religião e Política. Ditadura no Brasil. Alceu Amoroso Lima. Epistolografia.

\begin{abstract}
This paper analyzes how the Brazilian intellectual Alceu Amoroso Lima (1893-1983) reacted to the issuing of the Institutional Act No. 5 and the resulting strengthening of the civil-military dictatorship in Brazil. I examine the daily letters that Amoroso Lima sent to his daughter, the Benedictine sister Maria Teresa, throughout the year of 1969. Through this dialog, Amoroso Lima tried to redefine his public persona as a Catholic layman leader in face of the challenges and urgent demands in a time of deep political crisis.
\end{abstract}

KEYWORDS: Brazilian Catholic Thought. Religion and Politics. Dictatorship in Brazil. Alceu Amoroso Lima. Epistolography.

\footnotetext{
(*)Doutor em História pela Pontifícia Universidade Católica do Rio de Janeiro, graduado em História e Economia pela Universidade Federal Fluminense. Entre outros trabalhos, é autor do livro Um itinerário no século: mudança, disciplina e ação em Alceu Amoroso Lima (Loyola/PUC-Rio, 2006) e do texto sobre o Brasil para The Cambridge Dictionary of Christianity (Cambridge University Press, 2010). Atualmente, leciona no Programa de Mestrado em História do Brasil, da Universidade Salgado de Oliveira, em Niterói. Email:<marcelotimotheo@uol.com.br>
}

\footnotetext{
1 Agradeço ao Center for World Catholicism and Intercultural Theology, da DePaul University, onde, como Visiting Fellow, redigi este trabalho. Minha dívida de gratidão, portanto, a todos do CWCIT por sua gentil acolhida e, em especial, a seu diretor, William Cavanaugh, scholar e anfitrião exemplar. Cumpre ainda registrar que versão preliminar do presente argumento foi apresentada na IV Jornadas RELIGARSur, em Buenos Aires. Agradeço aos colegas organizadores do evento pela aceitação de minha ponencia e também aos comentários de Susana Monreal, da Universidad Católica de Uruguay. Por fim, dedico "Ofício das Trevas: Alceu Amoroso Lima na noite do arbítrio” a Lucia Ribeiro e Luiz Alberto Gómez de Souza.
} 
INTRODUÇÃO

Em fins de 1968, a ditadura imposta aos brasileiros desde 1964 aprofunda sua natureza de exceção. Naquele ano, o governo do general Arthur da Costa e Silva enfrentou grandes manifestações populares, que pediam a redemocratização do país, e a primeira greve operária do regime civil-militar. Tais movimentos impactaram as Forças Armadas, fazendo sua ala mais dura demandar maior repressão política. O chamado "golpe dentro do golpe" veio em 13 de dezembro de 1968. Tendo por pivô a negativa do Congresso nacional em conceder autorização para que fossem processados dois deputados oposicionistas, Márcio Moreira Alves e Hermano Alves, o governo decretou o Ato Institucional $\mathrm{n}^{\text {o. }} 5$. $^{2}$ Por intermédio do AI-5, o Poder Executivo passou a ter a prerrogativa de decretar o fechamento do Congresso, cassar mandatos parlamentares, suspender direitos políticos de qualquer cidadão por dez anos, intervir em Estados e Municípios, suspender a proteção do habeas corpus. Naquele mesmo dia, o Parlamento foi fechado. Ele só seria reaberto dez meses depois, para que referendasse a escolha, pelo Alto Comando do Exército, do general Emílio Garrastazu Médici para a presidência da República.

Nas linhas subsequentes, analisa-se como o intelectual leigo católico Alceu Amoroso Lima (1893-1983) acompanhou o acirramento da ditadura entre os brasileiros. Para tanto, examinar-se-á a correspondência de Amoroso Lima (que alternava seus dias entre suas residências do Rio de Janeiro e de Petrópolis) com sua filha, Lia (religiosa beneditina que adotou o nome Maria Teresa ao se enclausurar no Mosteiro de Santa Maria, em São Paulo). Sobre a fonte principal do presente estudo, diga-se o seguinte: Alceu Amoroso Lima escreveu diariamente à filha por mais de 30 anos, do início da década de 1950, quando Lia optou pela vida monacal, até 1983, ano da morte do pensador brasileiro.

\footnotetext{
2 As razões alegadas pelo governo de então são conhecidas: Márcio Moreira Alves (1936-2009), pouco antes do Dia da Pátria, ao protestar contra a violenta invasão da Universidade de Brasília pela polícia militar, proferira discurso na Câmara dos Deputados. Nesta manifestação, inspirado na peça clássica Lisístrata, pediu à população que não comparecesse aos desfiles militares comemorativos do 07 de setembro. Também propôs que "as moças, aquelas que bailam com cadetes e namoram jovens oficiais" passassem a recusar suas presenças. Já quanto a Hermano Alves (1927-2010), ele foi acusado de escrever artigos jornalísticos provocativos em relação ao governo federal, no jornal carioca Correio da Manhã. Isso posto, seja dito ser consenso entre os historiadores que as críticas dos mencionados deputados oposicionistas nada mais foram que pretexto para a radicalização do regime de exceção, ação realizada pelo setor mais duro das Forças Armadas. Obs.: para a citação do discurso de Moreira Alves, ver https://www.youtube.com/watch?v=F2Gs_ZrU-bY.
} 
Serão focalizadas aqui as cartas redigidas por Amoroso Lima entre janeiro e dezembro de 1969, correspondência publicada no livro Diário de um ano de trevas. 3 A consulta a esse material até há pouco inédito ilustra como o intelectual em questão vai buscando encontrar um rumo em meio à noite escura que se abateu sobre o Brasil.

Nas mencionadas cartas, Amoroso Lima divide com a filha certezas e dúvidas. Por um lado, está clara sua indignação frente ao governo ditatorial, regime que ele julga (com acerto, a propósito) irá sobreviver por 20 anos. 4 Por outro, ele reflete, por escrito, quanto à melhor maneira de se colocar diante dos novos tempos de fortalecido arbítrio. Maneira de reação, como se verá abaixo, não exatamente clara para o intelectual cristão, no imediato pós AI-5.

Assim, dia após dia, esquadrinhando a conjuntura, Alceu Amoroso Lima dialoga com Maria Teresa - que, antes da opção monacal, graduara-se em Literatura, na PUC-Rio - sobre suas ações diárias e incertezas quanto ao presente e ao porvir. E, ao mesmo tempo em que descreve seu cotidiano e faz ponderações e projeções, compondo rico retrato do Brasil de então, Amoroso Lima medita sobre sua atuação (e a eventual eficácia desta) como intelectual e crente, em dias de borrasca.

\section{DA REAÇÃO À MODERNIDADE AO CRISTIANISMO RENOVADOR}

Dadas as limitações espaciais desse trabalho, não será possível fornecer detalhado inventário biográfico de Alceu Amoroso Lima. 5 Homem de letras e de ação, convertido à Igreja aos 35 anos incompletos, tornou-se o mais importante pensador e líder leigo católico do Brasil contemporâneo. Da conversão à morte, esteve presente na praça publica nacional como fiel militante, unindo permanência e câmbio. Assim, se Alceu, por mais de 50 anos, manteve-se ligado à Igreja Católica, ele alterou significativamente suas eclesiologia e ação política, atuação sempre realizada em nome da fé. Tal transformação o levou, de forma não-retilínea e muitas vezes tensa, de um registro cruzadista, prosélito e reativo à modernidade, prevalente de fins dos anos 1920 até a segunda metade dos

\footnotetext{
3 Editado pelo paulistano Instituto Moreira Salles, em 2013.

4 A este respeito, ele cita, em repetidas ocasiões, o ex-ministro de João Goulart, Francisco de San Tiago Dantas, que, logo depois do golpe de Estado, teria confidenciado a Amoroso Lima estar se iniciando ditadura para as próximas duas décadas. Ver AMOROSO LIMA, 2013, entre outras, às páginas 41 (carta de 25/01), 53 (09/02) e 56 (19/02). Observação: como todas as cartas aqui arroladas foram redigidas em 1969, indicarei tão somente o dia e o mês de sua redação.

5 Para um inventário biográfico sumário de nosso autor, ver, por exemplo, COSTA, 2015, p. 21-32.
} 
1940, ao cristianismo renovador, em diálogo com o século, e à defesa de teses caras ao progressismo político, a partir da década de 1950. Transformação essa que fará Amoroso Lima antecipar algumas teses do Concílio Vaticano II (19621965), tornando-se seu ferrenho defensor. Transformação que, igualmente, fará de Alceu crítico contumaz da mais recente ditadura nacional. ${ }^{6}$

A defesa da Igreja conciliar e da volta ao Estado de Direito no Brasil são pontos centrais na correspondência compilada em Diário de um ano de trevas. No horizonte de ambos os campos, o eclesial e o político interno, Amoroso Lima divisa nuvens negras. Assuntos outros também lá estão: recordações da infância e da juventude do autor, tempo passado entre o Brasil e a Europa; bastidores da Academia Brasileira de Letras, da qual nosso missivista era membro desde os anos 1930; considerações espirituais; opiniões sobre a conjuntura mundial. Mas, seja reiterado, as grandes preocupações confidenciadas por Alceu à Ir. Maria Teresa dizem respeito aos rumos da Igreja universal e ao futuro do Brasil. Aquela, sob a liderança cada vez mais contestada de Paulo VI (papa de 1963 a 1978); o país, em sua mais dura provação cívica. No presente trabalho, embora reconhecida a relevância do debate eclesial, priorizar-se-á o relato amorosiano relativo a nosso cenário político interno.

\section{A ESCRITA COMO EXERCÍCIO DIÁRIO: AS MEDITAÇÕES DE ALCEU DE AMOROSO LIMA}

Antes de prosseguir, cabe entender melhor o conjunto documental em lume. Como informado previamente, Alceu Amoroso Lima escreveu cartas diárias para sua filha, do primeiro semestre de 1951, quando Lia interna-se em mosteiro beneditino tomando o nome Maria Teresa, até 1983, o derradeiro ano de vida do pensador brasileiro. A monja lhe respondia semanalmente, aos sábados.7

Em outro lugar, 8 interpretei o longo e ininterrupto (em vida, naturalmente) exercício epistolar de Amoroso Lima, tomando-o como parte de sua "tripla devoção diária". Tal expressão, cunhada pelo próprio intelectual católico, denomina as três atividades com as quais ele iniciava seu dia: participação na missa; recitação do Breviário, a oração oficial da Igreja latina;

6 Para os câmbios de Amoroso Lima - e da forma como ele, em movimento bastante sofisticado, os controlou - ver COSTA, 2006. Obra hoje disponível, para descarga gratuita, em http://www.editora.vrc.puc-rio.br/cgi/cgilua.exe/sys/start.htm?infoid=105\&sid=3.

7 AMOROSO LIMA, Ir. Maria Teresa, entrevista ao autor, 12/09/1999.

8 Ver COSTA, 2006, p. 193-224. 
escrita de carta à filha, relatando principalmente acontecimentos do dia anterior.

Isso posto, recordo e resumo o que dissera então, no livro Um itinerário no século: sem dúvida, quanto à escrita das cartas, está-se, primariamente, diante do diálogo entre pai e filha. Porém, o próprio Alceu indicou outro caminho interpretativo, que dará sentido complementar a sua volumosa correspondência com a Ir. Maria Teresa. E ele o faz ao conectar o trabalho da escrita à filha com outra de suas atividades diárias, a frequência à missa matinal. Assim deu-se, em fins dos anos 1970, quando Alceu foi entrevistado por Frei Betto, para número especial de periódico que celebrava a passagem dos 85 anos do intelectual católico. Na ocasião, ao ser perguntado como revigorava sua fé, Alceu respondeu:

Devo dizer com toda franqueza que, cada vez mais, amo a missa. [...] Se, a cada manhã, não fosse à missa e não escrevesse à minha filha - permita-me ligar as duas coisas -, não haveria esse reabastecimento. Só consigo realmente pensar durante a missa. (Revista Encontros com a Civilização Brasileira, 1978, p. 215)ํ.

Como se vê, Amoroso Lima relaciona o ato religioso central no catolicismo à atividade bem diversa, de âmbito familiar. Sabe que pode ser mal compreendido. Por isso, pede licença ("permita-me ligar as duas coisas") para dispor, lado a lado, culto público e costume doméstico. E, creio, a associação de ações tão díspares é reveladora: acredito que Alceu torna tal operação possível porque elevou em dignidade a última, o costume familiar em questão. ${ }^{10}$ Ele transfere, pois, algo de sublime ao ato de escrever à filha. Torna-o, de algum modo, sacramental. Vista dessa forma, a correspondência cotidiana com a monja, sua confidente por tanto tempo, transforma-se numa espécie de confissão.

Confissão laica, sem dúvida. Não se trata aqui de rogar perdão e obter absolvição, como acontece no sacramento católico da confissão, sendo o fiel o suplicante e o sacerdote o mediador do perdão divino. Mas o diálogo epistolar entre pai e filha contém outra característica importante da confissão, a orientação espiritual. ${ }^{11}$ Diálogo que, na definição da Ir. Maria Teresa, seria

\footnotetext{
9 A entrevista foi intitulada "Vida Cristã e Compromisso Político em Alceu Amoroso Lima". Ver sua reprodução integral às páginas 203-219 da citada revista.

${ }^{10}$ A outra opção era rebaixar o sacrifício eucarístico à condição de ato meramente secular, desprovido de sacralidade. Alternativa totalmente despropositada para um crente como Alceu.

${ }^{11}$ A rigor, a direção espiritual não inclui obrigatoriamente o sacramento da confissão, podendo aquela ser dispensada por religiosos não consagrados (já a última é prerrogativa de presbíteros, padres). Mas, nos meios católicos, é bastante comum o vínculo entre ser dirigido em termos espirituais e, em algum
} 
marcado pela "atitude de meditação" do pai (Amoroso LimA, Ma. Teresa, entrevista ao autor, 12/09/1999).

A expressão deve ser compreendida a partir do beneditinismo, universo de Maria Teresa desde que optou pela vida contemplativa. Na Regra de São Bento, o uso do verbo "meditar" permite interessante interpretação. Ali, em importante capítulo, aquele que versa sobre a maneira de receber os candidatos à vida monástica, lê-se: "Fique [o candidato], depois, na cela dos noviços, onde esses se exercitam, comem e dormem.” $(\operatorname{Rg} 58,5)^{12}$.

Não tenciono discutir a recepção recomendada aos que se apresentam à porta do Mosteiro, o móvel principal do capítulo 58 da acima aludida Regra. Desejo frisar que a palavra "exercitam", na versão latina original, é meditent, meditar. Ou, como assinala D. Basílio Penido, "meditar, verbo depoente, significa exercitar-se" (PENIDO, 1997, p. 174).13 No mesmo sentido, famoso comentador da Regra confirma que o termo meditent, aqui, quer dizer exercitarse (Herwegen, 1953, pp. 329-30). Ambos os especialistas registram que o exercício proposto por Bento tem inspiração militar. Basílio Penido lembra que, no Prólogo da Regra, o Mosteiro é definido como "uma escola de serviço do Senhor" (dominici schola servitii, $\operatorname{Pr} 45$; PENIDO, 1997, p. 14, nota 1). E esclarece: as scholae eram academias militares, formavam oficiais e praças das legiões romanas. Isto porque a definição do cristão (e, logo, do monge) como soldado de Cristo era comum nos séculos iniciais da Igreja. ${ }^{14}$ Já Herwegen lembra que, nas escolas militares antigas, medito (meditor), donde vem meditent, significa “exercitar, adestrar, experimentar" $(1953,329) .{ }^{15}$

Portanto, a correspondência familiar amorosiana, de pai para filha, deve ser entendida nessa clave. Alceu, escrevendo diariamente para a religiosa beneditina, e ele próprio tributário da espiritualidade de Bento (tornara-se oblato dessa Ordem, em meados dos anos 1950), exercitou-se, adestrou a si

momento, ser ouvido em confissão. Basta lembrar, no caso de nosso autor, a figura do Pe. Franca, seu diretor espiritual e confessor.

12 Utilizo a consagrada tradução do monge João Evangelista Enout (1998).

13 Apenas a título de ilustração, os verbos depoentes latinos são aqueles que têm forma especial distinta da fundamental ativa. A forma depoente é igual à da voz passiva, mas com outro significado.

14 Ver PENIDO, 1997, p. 174.

15 Vale lembrar a reflexão de Pierre Hadot. O falecido professor do Collège de France classificou a meditação como prática do diálogo com alguém, com terceiros ou consigo (1995, p. 91). Daí, Hadot evocou os diálogos platônicos, apontados por ele como exercícios espirituais modelares. Exercícios que definiriam um "itinerário de pensamento" onde "o ponto não é construir uma doutrina, mas guiar o interlocutor na direção de determinada atitude mental. É um combate, amigável mas real.” (p. 91) Através da exposição de Hadot - onde não faltou a imagem militar por mim grafada - confirma-se a conexão entre as ações de meditar e exercitar-se. 
mesmo, experimentou caminhos. Ele que, já alguns anos antes da ida de Maria Teresa para o claustro e também durante a década de 1950, ia remodelando seu registro de catolicismo, adotando eclesiologia e atuação política mais progressistas. Em suma: ao lançar-se por caminhos novos, Alceu Amoroso Lima procurou não se desorientar no trajeto.

Então, escrevendo, o líder católico avaliou riscos, procurou controlá-los, enquanto também modelava a si mesmo. Amoroso Lima que não contava mais com a presença do Pe. Leonel Franca, seu diretor espiritual desde a conversão, com quem se reunia semanalmente para ser ouvido em confissão e de quem ouvia orientações. ${ }^{16}$

Daí, com certa licença, poder-se chamar o epistolário aqui debatido de "confissão laica”. Ato importante para Alceu que, dialogando com a filha religiosa, a exemplo da confissão sacramental, examinava sua consciência. E, meditando (exercitando-se), organizava a si próprio, disciplinava-se ${ }^{17}$.

Propõe no corrente texto que, nos mais difíceis tempos da última ditadura brasileira, Amoroso Lima, já havendo completado sua transformação eclesiológica e política, acrescentará outro sentido aos exercícios espirituais realizados por intermédio das citadas cartas diárias. Cabia refletir (exercitar-se, meditar), objetivando novas ordenação interior e orientação para a ação. Em suma: para nosso autor, urgia refletir sobre qual seria seu papel, como intelectual e fiel cristão, na nova ordem nacional. É o que procuro analisar abaixo.

\section{UM CRISTÃO E SUA CIRCUNSTÂNCIA: O BRASIL EM TEMPOS DE CÓLERA}

Como seria de se esperar em epistolário do gênero, mensagens escritas de pai para filha, as cartas que Amoroso Lima envia à monja Maria Teresa abordam muitos assuntos: de temas estritamente da esfera privada, que foram suprimidos no processo editorial, a digressões sobre acontecimentos mais variados. Assim, entre o que foi efetivamente publicado, encontram-se

\footnotetext{
16 Sobre a confissão semanal de Amoroso Lima com o Pe. Franca, ver A. C. Villaça, entrevista ao autor, 13/06/2001.

17 Exame de consciência bastante ligado à ideia antiga de meditação como um exercício. Paul Veyne, na introdução a texto de Sêneca, lembra que os exercícios estóicos (e ele opera com argumento semelhante ao de I. Herwegen e B. Penido, relacionando o ato de exercitar-se ao de meditar, já que o grego mélété foi traduzido pelos romanos para "meditar") influenciaram fortemente a espiritualidade cristã. Diz o historiador francês que, dos exercícios pensados pelos estóicos, dois terão "futuro promissor" entre os cristãos: "o exame de consciência e aquilo que chamamos 'diários íntimos'.” (VEYNE, 1988, p. 21.)
} 
referências rápidas e também análises mais elaboradas acerca de múltiplos tópicos. Lá está, por exemplo, a tensa conjuntura mundial do fim dos anos 1960, da guerra do Vietnã (Amoroso LimA, 2013, p. 234, 25/11) às crescentes dificuldades de Charles de Gaulle no governo francês (p. 117, 28/4). E muito mais: temas literários e de cultura geral18; a chegada do homem à Lua ${ }^{19}$; referências (simpáticas) aos Beatles e aos hippies²0; bastidores (e fofocas) da Academia Brasileira de Letras, sobretudo quanto ao processo de eleição de novos membros. ${ }^{21}$ Contam-se também recordações do passado distante de Amoroso Lima, no Brasil e em França, ${ }^{22}$ e relatos de seu cotidiano recente, em Petrópolis e no Rio de Janeiro. ${ }^{23}$ E, no diálogo entre dois crentes, há pensamentos devocionais. Como aquele que o fiel Alceu confia à Maria Teresa: "Deus é perdão, eis o que hoje em dia faz a essência de minha fé.” (p. 129, 04/05) 24.

No entanto, como já salientado, abstraindo-se o universo familiar, os dois temas prevalentes nas cartas dizem respeito ao Brasil e à Igreja (com muito maior ênfase em Roma que em assuntos eclesiais locais). Mais exatamente, como também adiantado, os temas principais de Amoroso Lima, nas mencionadas cartas, são a situação política brasileira sob regime ditatorial e o que o intelectual católico apresenta como retrocessos eclesiológicos, teológicos e

\footnotetext{
18 Como é o caso da comparação, que pensava em desenvolver analiticamente, entre dois ícones das letras portuguesas e brasileiras, Luís Vaz de Camões e João Guimarães Rosa (AMOROSO LIMA, 2013, p. 74-5, 17/03).

19 Anotações de 20 e 21 de julho: ver Amoroso Lima, 2013, p. 197-200.

2o Para Beatles e hippies: ver Amoroso Lima, 2013, p. 104, 12/04. E, ainda quanto aos hippies, ver também p. $135,09 / 05$.

${ }^{21}$ Ver, p. ex., a carta de 31 de março, onde é mencionada a eleição para a sucessão do poeta Manuel Bandeira (AMOROSO LIMA, p. 88-9). Outro bom exemplo é a reiterada recusa de Amoroso Lima em apoiar a candidatura do general Lira Tavares, por ocasião de nova eleição de "imortal". Neste sentido, ver as cartas de 06 (p. 241) e 23 de dezembro ( p. 245). Na última mensagem, a revolta e a ironia de Amoroso Lima são flagrantes: "o Exército quer também por o dedão na Academia, e como lá dentro não falta quem esteja disposto a morrer para dar uma vaga, não tardarão os galões a dar entrada na casa do pobre do Machado [de Assis, fundador da ABL]" ( p. 245). Já em 12 de julho, também indo em direção contrária ao pleito de Lira Tavares, Amoroso Lima registra desejo que, reconhece, seria de difícil concretização: que Carlos Drummond de Andrade "vença suas [próprias] relutâncias", candidatando-se à mesma ABL (p. 191).

22 Bons exemplos são as lembranças de seu curto período como jovem diplomata, no Itamaraty (p. 69-70, 15/o3), e de suas temporadas - e fugazes amores - na Paris da belle époque (ver longa anotação de 27 de junho, p. 178-185). Ainda sobre o passado remoto, chamam atenção as impressões de seus primeiros contatos com o cinema, o automóvel e o avião, isto é, com a ideia e a prática do movimento acelerado. Ver p. 148-151, 01/o6.
}

23 Referências urbanas essas presentes em boa parte do epistolário em questão. Afinal, o autor dividia seu tempo entre duas residências fixas, nestas cidades.

$24 \mathrm{O}$ trecho foi grifado no original. Retirei a ênfase para que não contrastasse com os outros tópicos anteriormente elencados. 
políticos do papa Paulo VI, pontífice sob intensa pressão em rebanho católico cada vez mais dividido, no pós-Concílio Vaticano II. Papa cuja eleição fora aguardada e saudada por Alceu. ${ }^{25}$

A decepção de Amoroso Lima face ao pontificado de Paulo VI não poderá ser desenvolvida aqui, sua menção sinaliza intenção futura de trabalho. Como dito outras vezes nessas linhas, cabe agora acompanhar o relato de Amoroso Lima quanto ao regime vivido pelos brasileiros desde 1964, ditadura acirrada em dezembro de 1968. “Terríveis tempos” (AMOROso LiMA, 2013, p. 88) sintetiza ele, na carta de 28 de março do ano seguinte. Não sem motivo, ele assinala no cabeçalho da mesma: “[dia de] Nossa Senhora das Dores”, em raro registro retirado do missal romano (p. 86). Haveria algo mais revelador do estado de espírito amorosiano que a associação entre as agruras pátrias e o drama do Calvário traduzido no culto à Maria, Mãe Dolorosa?

Cumpre, na sequência, esclarecer como Amoroso Lima caracteriza tais "terríveis tempos" ao longo do Diário de um ano de trevas. Ele aponta a origem do governo inaugurado com a deposição do presidente constitucional João Goulart (1961-63): o novo regime seria fruto de uma "quartelada a mais na vida inglória de nosso modesto terceiro-mundo latino-americano.” (p. 93, carta de 02/o4.) Mais adiante, tendo apontado o que seria o vício inicial do governo civil-militar, o missivista define a natureza dos novos líderes da nação: "gangsters de galões" (p. 128, 04/05). Situação ainda agravada pela enfermidade do presidente Costa e Silva e sua substituição por Junta Militar ou, nas palavras de nosso autor, por uma "junta de coice” (p. 217, 03/o9). Para Amoroso Lima, a chegada de um triunvirato castrense ao poder, fato comunicado ao país em 31 de agosto de 1969, transformara o Brasil em algo "pior que republiqueta” (p. 219, 13/o9). Reveladora é a forma encontrada por ele para indagar sobre os beneficiários do recrudescimento do regime de exceção: “Cui prodest?”. Trata-se da expressão latina empregada, em meios

\footnotetext{
25 Amoroso Lima fora grande entusiasta de Giovanni Battista Montini - mesmo antes da eleição deste ao papado, com o nome Paulo VI. Bom exemplo de tal admiração encontra-se no relato de viagem Europa de hoje. Ali, ao recordar sua passagem por Roma, durante o Ano Santo de 1950, Alceu revela seu encantamento pelo então monsenhor Montini, a quem ouvira em série de três conferências. Entusiasmo que faz o brasileiro expressar o desejo de ver Montini feito sumo pontífice: "[...] aquele homem magro, marcado pelas vigílias e preocupações [...] será que um dia ouviremos aquele frágil caniço humano falar do alto do trono carmesim de São Pedro?” (AMOROSO LIMA, 1951, p. 315). E, quando da morte de Pio XII, em 1958, Alceu afirmou, em mensagem à Ir. Maria Teresa, que mantinha a esperança de ver Montini elevado à liderança máxima da Igreja, ainda que, naquela época, o prelado italiano não fosse cardeal. Tal opinião, registrada em carta, foi publicada no início do livro que Amoroso Lima dedicou a João XXIII (1966). Trata-se de raro exemplo de mensagem remetida à Maria Teresa que foi editada durante a vida do intelectual católico.
} 
forenses, para questionar a quem interessaria determinado delito (p. 215, 01/o9, grifo original).

Assim, os brasileiros, privados do Estado de Direito, viveriam no "reinado da impostura" (Amoroso LimA, 2013, p. 218, 03/09). Status quo confirmado pela escolha, pelo Alto Comando do Exército, do general Médici como "candidato" à presidência da República. Adiante, Amoroso Lima chega a elogiar o discurso de posse do novo mandatário; arenga que julga, em termos literários e de ideias abstratas, perfeita. Mas não haveria lugar para ilusões. Ao se perguntar sobre a significação concreta do discurso do presidente recémempossado, o líder leigo amplia o questionamento:

[O discurso do presidente significa] Que [Médici] não vai fazer as monstruosas injustiças que foram feitas com professores, alunos e operários? Vai mandar rever todos esses processos para eliminar os da mais clamorosa injustiça? Vai mandar reabrir as associações estudantis? Vai dar liberdade de imprensa real? E a anistia aos condenados políticos? E a revisão de todos os processos de cassação? (AMOROSO LIMA, 2013, p. 224-25, 31/10/1969. Grifo no original.)

Em seguida, Amoroso Lima arremata: "Se fizer tudo isso, sairá pelas mãos dos 'linhas duras'. Se não fizer, como é certo, não cumprirá o que prometeu.” (p. 225, 31/10).

Por sinal, quanto a programas de governo, Amoroso Lima antecipara, dias antes, o que lhe parecia ser o ideal: concessão da anistia política, fim dos banimentos e das cassações políticas, eleições livres, Judiciário e Legislativo independentes e com total autonomia. Enfim, que os mandatários da nação "restaurassem efetivamente um regime democrático." (p. 222, 08/10. Grifo no original). Porém, de imediato, ele mesmo acrescenta: "nada disso é possível”. (p. 222, 08/10).

Se a redemocratização mostra-se hipótese fantasiosa, é a dura realidade do dia-a-dia que foi pormenorizada nas cartas coligidas em Diário de um ano de trevas. Os exemplos são muitos: censura à imprensa; ${ }^{26}$ detenções arbitrárias; ${ }^{27}$ assassinatos como do Pe. Henrique Pereira Neto, sacerdote próximo a D. Hélder Câmara, e de não nomeado estudante que, após ter sido detido em São Paulo,

\footnotetext{
${ }_{26}$ Ver p. ex., p. 30 (17/o1); p. 50 (o7/o2); p. 106 (14/o4); p. 126 (01/o5) e p. 139 (14/o5).

${ }^{27}$ Assim, em 28 de janeiro de 1969, ele registra a prisão da historiadora Maria Yedda Linhares, sua antiga colega na Universidade do Brasil. Amoroso Lima voltará a apontar outras prisões em suas cartas: p. ex., p. 50 (07/02); p. 105 (12/04) e p. 233 (22/11).
} 
fora torturado e assassinado ${ }^{28}$; cassações de direitos políticos; ${ }^{29}$ aposentadorias compulsórias de professores universitários ${ }^{30}$.

Agravando o quadro, há ainda a autocensura dos próprios jornais. Alceu Amoroso Lima informa à filha ter sido vitima de supressão de alguns dos seus textos, censura determinada pelos redatores-chefes de periódicos onde assinava coluna, que, em difícil conjuntura, não desejavam melindrar os donos do poder ${ }^{3}$.

Tal quadro desolador e o silenciamento da imprensa fariam Amoroso Lima repensar, por desperdício, a leitura dos jornais. Nas palavras dirigidas pelo pai à filha, em 07 de maio de 1969:

Mais uma manhã perdida! Como se desperdiça tempo lendo coisas inúteis, como esses jornais [...] depois que o regime do assalto a que fomos submetidos nos priva das leituras políticas, que eram ao menos uma janela aberta, mesmo até 13 de dezembro de 68, data fatídica para a liberdade de expressão no Brasil [...]. (AMOROSO LIMA, 2013, p. 129.)

O que fazer diante de tal provação? Nesta sentença, resume-se inquietante interrogação subjacente ao epistolário amorosiano dos meses que se seguiram à imposição do AI-5. Alceu objetivava, por meio de sua cartas à monja Maria Teresa, divisar o caminho a seguir.

A incerteza quanto ao futuro imediato chega mesmo a inibir Amoroso Lima, tão prolífico escritor, na composição de novos textos para o Jornal do Brasil e a Folha de S. Paulo. Ele mesmo o diz, em 23 de janeiro de 1969: "Ainda continuo bastante inibido de escrever alguma coisa. Depois de 13 de dezembro, ainda não consegui escrever nada de novo.” (AMOROSo LimA, 2013, p. 35, 23/o1.)

Dois dias depois, ele retorna ao tópico: "Encerrar não digo minhas atividades, mas minhas preocupações de ordem política e ... calar a boca [...]”. ( p. $41,25 / 01)$.

Ainda nesta carta, em trecho posterior, Alceu questiona-se: "Será que estou capitulando?” (p. 42). Curioso ressaltar que, na mesma data, ao iniciar a mensagem, Amoroso Lima assinalou a festa litúrgica do dia, celebração relativa

\footnotetext{
28 Ver, para ambos os casos, cartas de 13/06 e 03/12, op. cit., p. 160 e 241.

29 Ver por exemplo, p. 17 e 19 (o3 e 04/01); p. 31 (17/o1); p. 107 (14/o4); p. 120, 121 e 123 (todas referentes à mensagem de 30/04).

30 Ver p. ex., p. 31 (17/01); p. 113 (26/04), p. 128 (04/05/1969).

${ }^{31}$ Ver, para o Jornal do Brasil: p. 60 e 159 (23/o2 e 13/o6); e, para a Folha de São Paulo: p. 200-01 e p. 206 (24/07 e 01/o8).
} 
à conversão do apóstolo Paulo. As indicações de festividades religiosas, como já disse acima, não são comuns no conjunto de cartas publicadas. Assim, ao sugerir que poderia desistir da tribuna jornalística, Amoroso Lima, em direção contrária, parece conjurar tal pensamento, recordando Paulo, convertido paradigmático, apologista e redator das epístolas que compõe o primeiríssimo cânone cristão, anterior mesmo aos Evangelhos. Paulo que, segundo esse mesmo cânon, não esmorecera no "bom combate" (2 Tm, 4) e morrera testemunhando sua fé.

Adiante, dias após realizar tal anotação, Amoroso Lima retorna ao tema. Sua crise interior afigura-se ainda mais densa: "E o que resta a um pobre cristão como eu é ... voltar à literatura. [...] Mas o remédio heróico seria quebrar a pena ou morrer. " ( p. 54, 09/02. Grifo original.)

\section{E ele continua:}

Mas como só se morre decentemente quando se faz totalmente todo o nosso dever, a angústia, como acontece sempre quando nos defrontamos com uma tirania quase intolerável, é saber onde está o dever. Quebrar a pena? Conspirar? Acomodar-se? (p. 54, 09/02. Grifo original.)

E, redigindo a Maria Teresa, as opções são pensadas:

se bem que a conspiração, a ação clandestina contra o regime, fosse a solução mais decente [...] o fato é que não tenho fibra nem gosto, nem idade para isso. Tenho mesmo de morrer, quebrar a pena ou ... deixar que a graça de Deus vá me inspirando a ação da pena e da palavra - já que sou, hoje em dia, incapaz de qualquer ação - no sentido de escrever e falar o que for possível, dentro desse regime de hipocrisia em que vivemos $[. .$.$] (p.54, 09/02).$

Já em o8 de abril, o pensador cristão indaga, tendo como mote a abertura de célebre poema de Carlos Drummond de Andrade: “E agora, José?” (p. 100.) E, após citar o literato mineiro, Amoroso Lima segue:

Tenho dado tratos à bola para saber sobre que vou passar a escrever, já que o território político está vedado [...] E o pensamento embotado pela falta de liberdade [...] assuntos proibidos [...] aquilo mesmo sobre o que eu gostaria de escrever: a política fascista e hipócrita que desceu essa cortina de ferro na qual vivemos e sobre a qual ninguém fala. ( Grifo meu.) ${ }^{32}$

Impedido de denunciar, Amoroso Lima desabafa com a filha. Cabe frisar o ponto: ainda se está por estudar o papel da Ir. Maria Teresa na construção da obra paterna. Sabe-se que ela mantinha arquivo com cópia de todos os artigos

32 A aproximação com as ditaduras comunistas do Leste Europeu, tão anatematizadas pelas forças direitistas, é evidente. 
do pai.33 E ele a consultava quando tinha oportunidade de publicar coletâneas de textos. Assim foi por ocasião do cinquentenário de Alceu Amoroso Lima como crítico cultural (atividade iniciada em 1919). Em 1969, a reedição festiva da crítica literária amorosiana foi executada após consultas à Maria Teresa. Deste esforço, resultou a obra Meio Século de Presença Literária. ${ }^{34}$ Assim também o foi no momento de se coligir os necrológios que Amoroso Lima redigiu de 1945 até o início da década de 1970, depois reunidos sob o título Companheiros de Viagem (1971). No epistolário aqui analisado, o escritor é definitivo quanto ao papel desempenhado pela monja na publicação de seus livros: "Só você [Maria Teresa] é que tem ordem na cabeça para pôr ordem nesses volumes!” (p. 34, 22/o1. Grifo no original.)

Ao fazer o agradecimento, ele se referia explicitamente às duas obras citadas acima e a mais outro livro: Adeus à disponibilidade e outros adeuses, onde destacavam-se textos memorialísticos, compilação também editada para marcar o referido cinquentenário do autor. 35 Enfim, de pai para filha, é feito o reconhecimento: "Sem você nenhum deles [da trinca de livros] sairia!" ( p. 34, 22/o1. Grifo no original.)

Portanto, de maneira um tanto livre, adaptando célebre expressão utilizada para definir a Tradição eclesial romana (Depositum Fidei, "depósito dos fiéis"), creio ser possível sugerir que a monja Maria Teresa era a "fiel depositária” da memória textual do pai, líder católico reconhecido.

Há mais. A religiosa em questão atuou, por meio do aludido diálogo epistolar, como incentivadora do cultivo memorial paterno. E Alceu Amoroso Lima reconheceu tal atuação. Trechos contidos nas cartas de 03 e o9 de junho, por exemplo, registram a reação de nosso autor aos pedidos de Maria Teresa para que escrevesse sobre seu passado - ou sobre as "nuvens de outrora", como classifica ele, valendo-se da expressão francesa "neiges d'antan" (p. 153 e p. 155).

Ainda na clave biográfica, Amoroso Lima escreve para sua especial confidente, ao findar o ano de 1969, fazendo o balanço de sua vida. Estava

\footnotetext{
33 Fato confirmado pelo cardeal Arns, que viu tal arquivo, ao autor destas linhas. ARNS, Paulo Evaristo, entrevista, 18/03/1999.

34 A primeira referência ao trabalho de elaboração do que viria a ser Meio Século de Presença Literária é feita em 01 de janeiro de 1969 (AMOROSO LIMA, 2013, p. 15). A construção de Meio Século de Presença Literária será assunto contumaz entre pai e filha, nos dias seguintes. O livro foi lançado pela José Olympio carioca, no mesmo ano de 1969.

35 Esta última obra foi veiculada pela carioca Agir, também 1969.
} 
desejoso: "de olhar para mim [si] mesmo e tentar avaliar em que posição me encontro [se encontrava] neste final de carreira." ( p. 248, 29/12).

Há ainda mais. Em sua correspondência, Amoroso Lima também reporta os avanços em trabalhos editoriais outros. Ilustro o ponto com uma dupla de comentários. Em 28 de fevereiro, ele afirma ter logrado dar continuidade a textos para série intitulada "Direitos do Homem" (que foi publicada em livro apenas em meados dos 1970). E, em 26 de junho de 1969, ele informa à Maria Teresa ter finalizado a seleção da antologia dedicada ao poeta Manuel Bandeira ${ }^{36}$.

Em resumo: Maria Teresa desempenhou papel fundamental para Alceu Amoroso Lima, seja na ordenação da obra do pai, seja no incentivo para que ele relatasse seu passado e ao ouvir (e opinar) sobre textos paternos futuros. Emblemático é o pedido, da parte do veterano intelectual, publicado na abertura de Diário de um ano de trevas. Ali, ele solicita à filha opinião sobre dado projeto editorial: "Pense e me diga o que pensa", escreve. (p. 15, 01/o1).

E, em acréscimo, nas cartas para Maria Teresa, o líder católico reporta suas atividades de escrita não destinadas à publicação. Assim foi quando comunicou à filha estar redigindo parecer editorial referente à obra de desconhecido autor espanhol.37 E, muito importante, assim foi na mensagem de 13 de junho, quando revelou ter recebido, de D. Aloísio Lorscheider, então secretário-geral da Conferência Nacional dos Bispos do Brasil (CNBB), pedido para que formulasse relatório confidencial relativo à situação nacional (p. 160). O documento resultante da demanda de D. Aloísio, firmado por Alceu em 26 de julho de 1969, permaneceu inédito por muito tempo, tendo divulgação mais ampla graças a Kenneth Serbin. Para o pesquisador norte-americano, tal relatório, produzido por Amoroso Lima na forma epistolar, constitui "das cartas mais perspicazes e extraordinárias de que se tem notícia.” (SERBIN, 2001, p. 125.)

Em determinada passagem da missiva ao bispo Lorscheider, Amoroso Lima posiciona-se:

Creio que a Igreja, com sua imensa responsabilidade na direção das consciências, não pode silenciar perante os abusos inomináveis que continuam a ser praticados, contra as consciências, contra os direitos mais elementares, contra os conselhos mais evidentes de fidelidade à experiência do nosso

\footnotetext{
${ }^{36}$ Para o andamento da série de artigos sobre a Declaração Universal dos Direitos Humanos, ver op. cit., p. 60. Para a edição sobre Bandeira organizada por Amoroso Lima, ver op. cit., página 175 e seguintes.

37 Carta de 30 de junho, p. 186.
} 
passado nacional e às exigências de nosso futuro de nação em franca expansão demográfica. (SERBIN, 2001, p. 129.)

Mais adiante, o líder leigo afirma:

Cabe à Igreja, guarda das qualidades mais puras do caráter humano, velar para que um regime desfibrador do caráter nacional como esse que nos infelicita, possa ser removido, não por meios violentos ou revolucionários. Mas por meio de uma transformação legal das instituições vigentes, abrindo caminho à liberdade que é o único meio de restituir a responsabilidade a todos nós, que devemos, cada um em nosso posto, participar do governo do bem comum nacional. (p. 130).

E, na sequência, Amoroso Lima arremata: "Para isso a ação espiritual e racional da Igreja poderá concorrer de modo decisivo, se não silenciar ou comprometer-se". (p. 130).

Como se vê, o relatório é importante de fato. Documento formulado em segredo, em tensa conjuntura, e sobre cuja gênese Maria Teresa fora informada em primeira mão.

\section{CONCLUSÃO}

O conjunto de cartas aqui evocado testemunha, pois, especial diálogo.

Como salientado anteriormente, Amoroso Lima exercitou-se (no sentido beneditino do termo) ao escrever para a monja Maria Teresa, cumprindo o ultimo terço de sua autodenominada "tripla devoção diária”. Assim era desde o início de tal atividade epistolar entre pai e filha. Atividade comparável, já se disse, a uma confissão laica. Já foi igualmente dito que, nos anos 1950, quando Lia se internou no Mosteiro adotando o nome Maria Teresa, Alceu Amoroso Lima fez dela sua confidente. Tratava-se de manobra prudencial. Nesta década de 1950, o intelectual católico acelerava e consolidava seu câmbio eclesiológico, passando de registro de fé reacionário a outro, progressista. Dialogando com Ir. Maria Teresa, ele tentava controlar os riscos desta transformação, organizar-se para seguir adiante. Busca de autodisciplina que se manteve ao longo do tempo. Nesse sentido, em 22 de fevereiro de 1964, nosso autor escreve para a filha a seguinte mensagem (que faz parte de conjunto de cartas que vieram a público antes de Diário de um ano de trevas):

Você que qualifique como quiser, o que sinto por dentro e me alivio, consideravelmente, confiando apenas a você (pois poderia fazê-lo a uma pessoa que deveria ser meu confessor, e cheguei mesmo a pedir-lhe que o fosse quando morresse o padre Franca, naturalmente D. Timóteo [Amoroso Anastácio, monge beneditino e primo do intelectual em questão], mas por vários motivos não consigo nunca confessar-me com ele, de modo que me confesso com você, já que não se trata propriamente do sacramento, mas de confiar o tumulto do que vai cá dentro e com isso ... tranquilizar as águas [....]. (AMOROSO LIMA, 2003, p. 334.) 
Sob este prisma, também devem ser compreendidas as recorrentes indagações de Amoroso Lima quanto a sua escrita jornalística, alvo de vigilância intensa e de censura no Brasil do pós AI-5. Era tempo de se calar (na expressão amorosiana lembrada por três vezes mais acima, de "quebrar a pena")? Ou seguir enviando textos aos jornais, ainda que sob risco de perseguição política?

Risco, a propósito, do qual nosso autor estava bem consciente. Em pelo menos duas ocasiões, no decorrer do ano de 1969, ele avaliou a hipótese de ter que se submeter ao exílio. Hipótese consignada em cartas. ${ }^{3} 8$

Em Diário de um ano de trevas, os questionamentos de Amoroso Lima acerca do papel público que deveria desempenhar como intelectual cristão e também sobre a efetiva repercussão de suas eventuais ações, em um país silenciado pela força, não têm resolução formal, definitiva. Porém, em meio às indefinições nacionais e pessoais, o intelectual em foco segue redigindo seus textos, entre os quais aqueles que contestam o regime estabelecido e pedem a redemocratização. Assim será até sua morte, em 1983, já em tempo de maior abertura política que os governos de Costa e Silva e de Médici, mas ainda de vigência da ditadura. Não sem motivo, Alceu Amoroso Lima será considerado por opositores do regime civil-militar, religiosos e não crentes, como das mais assíduas e antigas vozes críticas à ditadura39.

Retorne-se aos "terríveis tempos" de 1969, como o personagem aqui analisado os crismou. Mais precisamente, volte-se ao mês de dezembro daquele ano, época propícia a balanços e prognósticos. E Amoroso Lima, em mensagem para Ir. Maria Teresa, não se furta a fazê-los. Em primeiro lugar, ele resume o que observou, no cenário interno, ao longo de todo o ano. Para o intelectual católico, o regime inaugurado em 1964 e radicalizado no final de 1968 "[...] introduzi[ra] o terror como elemento capital de nossa evolução política! O terror e a tortura! Plena barbárie!” (Amoroso Lima, 2013, p. 240, 03/12. Grifo meu.)

\footnotetext{
${ }^{38}$ Ver correspondência de 24 de janeiro e 19 de junho. AMOROSO LIMA, 2013, p. 36 e p. 166.

39 Nesse sentido, tome-se a homenagem a Amoroso Lima prestada pela revista Encontros com a Civilização Brasileira, em dezembro de 1978, número especial que celebrou o $85^{\circ}$. aniversário do intelectual católico. No volume em questão (para referência completa, ver bibliografia), foram reunidos personagens de destaque no cenário nacional, objetivando saudar a atuação de Amoroso Lima na praça pública durante o longo período de exceção que então vivia o país. $O$ tributo foi capitaneado pelo diretor da publicação, Enio Silveira, conhecido por sua vinculação com o Partido Comunista. Da homenagem, participaram cristãos e não-crentes. Entre aqueles, D. Paulo Evaristo Arns, cardeal arcebispo de São Paulo, dos mais destacados adversários do regime ditatorial entre a hierarquia eclesial; Leonardo Boff e Frei Betto, frades ligados à Teologia da Libertação; os homens de letras Otto Lara Resende e Otto Maria Carpeaux; o psicanalista Hélio Pellegrino. Já os que não professavam fé religiosa eram representados pelo arquiteto Oscar Niemeyer, os intelectuais Antônio Houaiss e Nelson Werneck Sodré e pelo próprio Énio Silveira. Todos, sem exceção, contrários ao governo estabelecido.
} 
Contudo, na mesma data, sem fornecer razões concretas, Amoroso Lima escreve à filha monja: "Mas a Luz virá! Virá! Virá!” (p. 241) 40.

Acredito valer, pela derradeira vez, a recordação do beneditinismo de Alceu Amoroso Lima (e da Ir. Maria Teresa, sua confidente contumaz). Como se sabe, Bento de Núrsia, ao lançar as bases do monaquismo ocidental, buscava dar resposta à desagregação do mundo clássico, nas ruínas do Império Romano sitiado por invasões bárbaras. Aliás, no violento contexto brasileiro do pós AI-5, o uso da palavra "barbárie" por Amoroso Lima não parece ser mera coincidência.

E, segundo a leitura tradicional católica, a iniciativa de Bento teria lançado as fundações da Europa. Continente cuja filiação espiritual à Igreja latina muito atribui-se ao mesmo Bento de Núrsia. Por isso, de acordo com esta linha de raciocínio, o papa Pio XII, já em meados do século XX, no pós-Segunda Guerra Mundial, dedicou a São Bento a encíclica Fulgens Radiator, "Luz Fulgurante”.

Creio que, em novos e sombrios tempos, Amoroso Lima, oblato beneditino, em seu cotidiano diálogo com a monja beneditina Maria Teresa, buscou acessar o espírito deste santo. Assim ele, escrevendo à filha religiosa, meditou/exercitou-se quanto à dura situação política interna do Brasil. Movimento pelo qual Amoroso Lima pretendeu melhor discernir o caminho a ser percorrido em meios às trevas. Tratava-se, com base em determinada leitura de fé, de tentar enxergar, em noite escura da história brasileira, a presença da Luz.

\section{REFERÊNCIAS}

AARÃO REIS, Daniel et alii. A ditadura que mudou o Brasil. Rio de Janeiro: Zahar, 2014.

AMOROSO LIMA, Alceu. Cartas do Pai. São Paulo: Instituto Moreira Salles, 2003. . Companheiros de viagem. Rio de Janeiro: José Olympio, 1971.

\footnotetext{
$40 \mathrm{O}$ registro da sobrevivência da Esperança cristã diante de quadro exasperante não é inédito em Amoroso Lima. Ele, em exemplo bastante emblemático, já operara analogamente décadas antes, ao redigir longa apresentação à edição brasileira de Noite de agonia em França, livro no qual Jacques Maritain trata da derrota de seu país frente ao Reich de Hitler, em 1940. Amoroso Lima, que também traduziu a citada obra de Maritain, finaliza seu texto introdutório, datado da Quarta-Feira de Cinzas de 1941, dizendo: "As sombras da noite ainda cobrem as terras em que dormem tantos mortos e onde sofrem, em vigília insone, tantos vivos. [...] É preciso 'esperar contra a esperança'. A mortificação e a penitência da Quaresma não valem nada por si mesmas, mas pela luz a que nos encaminham no Domingo da Ressurreição." (MARITAIN, 1941, p. 129).
} 
Diário de um ano de trevas. São Paulo: Instituto Moreira Salles, 2013.

Europa de hoje. Rio de Janeiro: Agir, 1951.

João XXIII. Rio de Janeiro: José Olympio, 1966.

Meio século de presença literária. Rio de Janeiro: José Olympio, 1969.

Memorando dos 9o. Entrevistas e depoimentos coligidos por Francisco de Assis Barbosa. Rio de Janeiro: Nova Fronteira, 1983.

Vozes, 1973.

Memórias improvisadas. Diálogos com Cláudio Medeiros Lima. Petrópolis:

COSTA, Marcelo Timotheo. Brazil. In: PATTE, Daniel (org.). The Cambridge

Dictionary of Christianity. Cambridge: Cambridge University Press, 2010, p. 140148.

. No torvelinho da História: o itinerário de Alceu Amoroso Lima. In:

MAGALHÃES, Luiz Edmundo de (org.). Humanistas e cientistas do Brasil. São Paulo: Edusp/SBPC, 2015, p. 21-32. Volume "Ciências Humanas".

Um itinerário no século. Mudança, disciplina e ação em Alceu Amoroso Lima. São Paulo/Rio de Janeiro: Loyola/PUC-Rio, 2006.

ENOUT, João Evangelista (tradução). A Regra de São Bento. 2 ed. Juiz de Fora: Mosteiro da Santa Cruz, 1998.

HADOT, Pierre. Philosophy as a way of life. Spiritual exercises from Socrates to Foucault. Oxford/Cambridge: Blackwell, 1995.

HERWEGEN, Ildefonso. Sentido e espírito da Regra de São Bento. Rio de Janeiro: Lumen Christi, 1953.

MARITAIN, Jacques. Noite de agonia em França. Rio de Janeiro: José Olympio, 1941.

NAPOLITANO, Marcos. 1964: história do regime militar brasileiro. São Paulo: Contexto, 2014.

PENIDO, Basílio. A escolha de Deus. Comentário sobre a Regra de São Bento. 2 ed. Juiz de Fora: Mosteiro da Santa Cruz, 1997.

SERBIN, Kenneth. Diálogos na Sombra. Bispos e militares, tortura e justiça social na ditadura. São Paulo: Cia das Letras, 2001.

SOUZA, Luiz Alberto Gómez de. Amoroso Lima e o Diário de um Ano de Trevas. Mimeo, 2011.

[VVAA]. REVISTA ENCONTROS COM A CIVILIZAÇÃO BRASILEIRA: Rio de Janeiro: Civilização Brasileira, número especial, dezembro de 1978.

VENTURA, Zuenir. 1968: o ano que não terminou. Rio de Janeiro: Nova Fronteira, 1988.

VEYNE, Paul. La Medication Interminable. In: SÉNÈQUE. De la tranquilitté de

l’âme. Paris/Marselha: Rivages, 1988. 